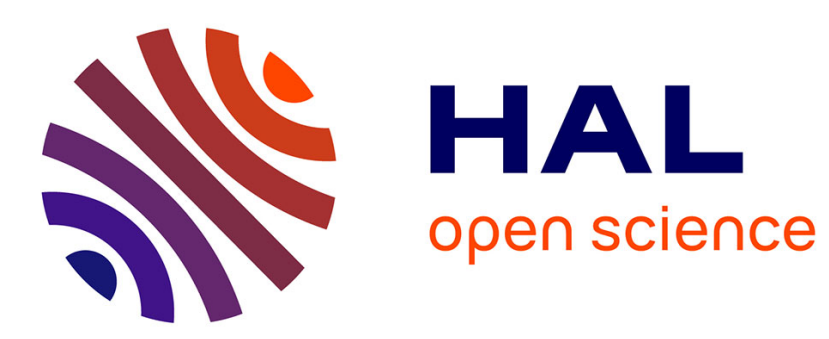

\title{
Development of SCARs useful for species identification in the genus Lolium
}

Valérie Delozier, Didier Peltier, Raymond Jalouzot

\section{To cite this version:}

Valérie Delozier, Didier Peltier, Raymond Jalouzot. Development of SCARs useful for species identification in the genus Lolium. Agronomie, 1999, 19 (2), pp.145-153. hal-00885922

\section{HAL Id: hal-00885922 \\ https://hal.science/hal-00885922}

Submitted on 1 Jan 1999

HAL is a multi-disciplinary open access archive for the deposit and dissemination of scientific research documents, whether they are published or not. The documents may come from teaching and research institutions in France or abroad, or from public or private research centers.
L'archive ouverte pluridisciplinaire HAL, est destinée au dépôt et à la diffusion de documents scientifiques de niveau recherche, publiés ou non, émanant des établissements d'enseignement et de recherche français ou étrangers, des laboratoires publics ou privés. 


\title{
Original article
}

\section{Development of SCARs useful for species identification in the genus Lolium}

\author{
Valérie Delozier, Didier Peltier, Raymond Jalouzot* \\ Groupe de biochimie et de biologie moléculaire végétales, laboratoire de génétique, U.F.R. sciences, 2, bd Lavoisier, \\ 49045 Angers cedex, France
}

(Received 8 September 1998; accepted 20 December 1998)

\begin{abstract}
In order to obtain some species-specific sequences, random amplified polymorphic DNAs were analysed in two varieties belonging to Lolium mutiflorum Lam. and four belonging to Lolium perenne L. First, analysis was performed on bulks of individuals in order to screen oligonucleotides allowing amplification of species-specific bands. Then, we tried to amplify eight selected markers from 34 individuals belonging to $L$. perenne $\mathrm{L}$. var. 'baltic' and 34 belonging to L. multiflorum Lam. var. 'wewo westerworld'. Southern hybridizations were performed in order to enhance detection of amplification products and to verify fragments homologies. We assessed the level of representation of putative markers in those varieties. Two markers were retained as species-specific ones. The sequences of both markers showed a strong homology to each other, allowing us to produce codominant sequence characterized amplified regions (SCARs). They allowed us to distinguish between the two studied varieties and were efficient enough to discriminate 13 other varieties in bulk analyses. (@ Inra/Elsevier, Paris.)
\end{abstract}

\section{L. multiflorum Lam. / Lolium perenne L. / RAPD marker / SCAR}

Résumé - Développement de SCAR pour l'identification d'espèces dans le genre Lolium. Nous avons utilisé la technique RAPD (ADN polymorphe amplifié au hasard) sur deux variétés de Lolium multiflorum Lam. et quatre de Lolium perenne $\mathrm{L}$., dans le but de développer des régions amplifiées de séquence connue (SCAR). Dans un premier temps, nous avons trié les amorces générant des profils polymorphes entre ces espèces, sur des mélanges d'individus. Puis nous avons amplifié les huit marqueurs RAPD sélectionnés, à partir de l'ADN de 34 individus pour la variété « baltic » de $L$. perenne L. et pour la variété « wewo westerworld » de L. multiflorum Lam.. Nous avons réalisé des hybridations afin d'accroître la sensibilité de la détection des produits d'amplification et de vérifier l'homologie de séquence entre fragments de même taille. Nous avons ainsi pu estimer le degré de représentation de ces marqueurs potentiels dans ces deux variétés. Finalement, seuls deux marqueurs spécifiques des deux variétés étudiées ont été retenus. Ces marqueurs ont montré une forte homologie de séquence et nous ont permis de dériver des SCARs codominants. Ils ont également permis de différencier 13 autres variétés lors d'analyses en mélanges de plantes. (@ Inra/Elsevier, Paris.)

\section{L. multiflorum Lam. / Lolium perenne L. / marqueurs RAPD / SCAR}

Communicated by Hervé Thiellement (Geneva, Switzerland)

* Correspondence and reprints

jalouzot@univ-angers.fr 


\section{INTRODUCTION}

The genus Lolium contains most of agronomically important temperate forage grass species. Lolium perenne $\mathrm{L}$. and $L$. multiflorum $\mathrm{Lam}$. are two species from this genus widely cultivated. $L$. perenne $\mathrm{L}$. is used in mixes for greens or pastures while L. multiflorum Lam. is harvested to make hay or silage.

L. perenne L. and L. multiflorum Lam. can naturally cross-hybridize. Studying interspecific crossing, Naylor [17] states that, despite the fact that the two species overlap in their geographical distribution, they can be distinguished morphologically but not consistently in genetical terms, since no difference in chromosome organization was found and they can interbred without difficulty; so L. multiflorum Lam. was first considered as a L. perenne L. subspecies [3]. Terell [29], quoted by Charmet and Balfourier [1], distinguished eight species in the genus: two of them are L. perenne L. and L. multiflorum Lam. More recently, Charmet and Balfourier [1], analysing isozyme polymorphism, have not revealed any specific allele allowing differentiation of these two species. However, the mean allelic frequency of some alleles, such as Pgi2-d, Prx-b or Dia-b alleles, clearly allowed us to distinguish between the two species. Stammers et al. [27] using RAPD markers (random amplified polymorphic DNA) estimated genetic distance between six Lolium and nine Festuca species. They found that Lolium species are very close, Nei's genetic distance [18] ranging from 0.032 to 0.068 . Charmet et al. [2] performed RAPD and RFLP analyses, PCRamplifications of six non-coding regions of chloroplastic DNA and sequencing internal transcribed spacers (ITSs) on eight species of ryegrass (Lolium) and 11 species of fescue (Festuca). In all studies, $L$. perenne L. and L. multiflorum Lam. appeared to be very close. The ITS-derived phylogenetic tree appeared to be the one with the best resolution and revealed that, among outbreeding Lolium species, perennial ryegrass seems to have differentiated last.

Although L. perenne L. and L. multiflorum Lam. are easily morphologically recognizable at the plant stage, they are very similar at the seed one. This fact makes purity analysis of seed batches very difficult.
Controls are performed after germination on 10 day-old plantlets, a procedure that is long and tedious. We, therefore, plan to use molecular assay in order to detect specific contaminants. The statutory policy relative to quality of seed batches rejects those containing more than one seed of $L$. multiflorum Lam. out of 25000 of $L$. perenne $\mathrm{L}$. in a batch and vice versa.

Previous works reported the use of molecular hybridization in order to detect contaminant in cytoplasmic male sterile seed stocks $[16,24]$ with a sensitivity of one out of 1000 . This involves having at disposal a sequence characteristic of the contaminant. Screening for such a sequence can be performed using various techniques such as RAPD analysis [30, 31], RFLP [15, 20] or AFLP [7]. Out of these, we chose random amplified polymorphic DNA (RAPD), a technique derived from polymerase chain reaction (PCR) technology [22]. Although its reproducibility has been discussed [13, 21 ], it represents a convenient tool for marker screening. It has been proved to limit time cost, the amount of DNA required and to reveal polymorphic loci.

The aim of this work was to identify RAPD markers present in all individuals belonging to the $L$. perenne $\mathrm{L}$. species but which do not exist in any individual belonging to the $L$. multiflorum Lam. species and vice versa. These markers could then be used to generate sequence characterized amplified regions (SCARs) [19]. The higher sensitivity and reproducibility of the PCR technique using SCARs rather than RAPD makes it usable to determine whether a batch of seeds for one of these two species of Lolium contains seeds belonging to the other Lolium species described or not.

Nevertheless, commercial varieties of Lolium perenne L. and L. multiflorum Lam. are synthetic varieties and therefore the level of heterozygosity is significative. It means that genetic differences exist between individuals belonging to the same variety. One can envisage the case in which a marker is absent only in $5 \%$ of individuals. If such individuals are contaminating a batch of seeds, they could not be detected. Thus, we planed to work with DNA 
extractions from individual plants in order to estimate the level of representation of selected markers.

We realized RAPD amplifications of DNA from bulks and then from 34 individual plants for each variety. Homologies between the amplified products were checked by hybridization. This paper describes the distribution of eight RAPD markers in two varieties of Lolium and the potential use of the two species-specific markers retained to detect contamination.

\section{MATERIALS AND METHODS}

\subsection{Biological materials}

Plant batches of about 30 individuals were supplied and the absence of contamination was checked by the Station nationale d'essais des semences (Beaucouzé, France). They are batches $35467,35318,35319,35363$ and 35074 for L. perenne L. and 25, 373 and 35437 for L. multiflorum Lam. A second subset of varieties was further studied, namely Herbie, Bastion and Barcredo for L. perenne L., and Adret, Tonyl, Vitesse and Barspectra for L. multiflorum Lam.

Studies at the individual level were performed on 34 plants from $L$. perenne $L$. var 'baltic' and 34 from $L$. multiflorum Lam. var. 'wewo westerworld' supplied by J. Lallemand (GEVES, Magneraud, France).

\subsection{DNA isolation and analysis}

DNA was isolated from individual plant leaf tissues with the DNeasy' mini extraction kit (Qiagen) according to the suppliers, or from leaf mixes of all the plants, according to Dellaporta et al. [4].

RAPD reactions were performed with 25 -ng template DNA, $0.2 \mathrm{mM}$ random primer (Operon), $100 \mathrm{mM}$ each 4 dNTP (Eurogentec), 1.5 unit Taq DNA polymerase (Promega), $2 \mathrm{mM} \mathrm{MgCl}$, $75 \mathrm{mM}$ Tris- $\mathrm{HCl} \mathrm{pH9,} 20 \mathrm{mM}$ $\left(\mathrm{NH}_{4}\right)_{2} \mathrm{SO}_{4}, 0.01 \%(\mathrm{w} / \mathrm{v})$ Tween 20 in a final volume of $25 \mu \mathrm{L}$. The reaction mix was overlaid with two drops of mineral oil.

Since variations have been reported with Taq DNA polymerase brands [13], the same Taq DNA polymerase brand was used for amplifications carried out for a given primer.

DNA amplifications were performed on a Crocodile III (Appligene) thermal cycler programmed for one cycle of 4 min at $94{ }^{\circ} \mathrm{C}, 1 \mathrm{~min}$ at $36{ }^{\circ} \mathrm{C}, 2 \mathrm{~min}$ at $72{ }^{\circ} \mathrm{C}$, followed by 45 cycles of $1 \mathrm{~min}$ at $94^{\circ} \mathrm{C}, 1 \mathrm{~min}$ at $36^{\circ} \mathrm{C}, 2$ min at $72{ }^{\circ} \mathrm{C}$, and finally one cycle for $1 \mathrm{~min}$ at $94^{\circ} \mathrm{C}, 1$ min at $36^{\circ} \mathrm{C}$ and $20 \mathrm{~min}$ at $72{ }^{\circ} \mathrm{C}$.

Amplification products were analysed by electrophoresis in $1.4 \%$ agarose gels and visualized by ethidium bromide staining. The sizes of the amplified fragments were estimated by comparison with the $1-\mathrm{kb}$ DNA ladder from BRL.

RAPD fragments, used for cloning or labelling, were recovered from agarose gels according to the technique described by Tautz and Rentz [28].

\subsection{Cloning of the selected fragments}

RAPD fragments, recovered from agarose gels, were cloned in the pGEM-Teasy Vector (Promega) following the manufacturer's instructions.

\subsection{Hybridization}

DNA was transferred from gels to Hybond ${ }^{\mathrm{TM}}-\mathrm{N}$ Nylon membranes (Amersham) by capillary Southern blotting [23, 26]. Transferred DNA was bound to the membranes by $3 \mathrm{~min}$ of UV-ray exposure.

The bands of interest were excised from another RAPD gel electrophoresis and eluted from agarose on a rock wool filter or excised from plasmid DNA by restriction enzyme. The eluate was radiolabelled by random priming with the kit Ready To Go (Pharmacia Biotech) according to the manufacturer's instructions.

Hybridizations were performed overnight at $65^{\circ} \mathrm{C}$ in hybridization buffer $5 \times$ SSPE $(20 \times$ SSPE: $3.6 \mathrm{M} \mathrm{NaCl}$, $0.2 \mathrm{M} \mathrm{NaH}_{2} \mathrm{PO}_{4}, 0.02 \mathrm{M}$ EDTA), $0.5 \%$ (w/v) SDS). Blots were washed twice at low stringency $(2 \times$ SSPE, $0.1 \%(\mathrm{w} / \mathrm{v}) \mathrm{SDS}$ ) and room temperature, then at medium-high stringency $(1 \times \mathrm{SSPE}, 0.1 \%(\mathrm{w} / \mathrm{v})$ SDS $)$ and $65^{\circ} \mathrm{C}$, and finally at high stringency $(0.1 \times$ SSPE, $0.1 \%$ (w/v) SDS) and $65^{\circ} \mathrm{C}$.

After washes, blots were autoradiographed using Xray films (Kodak). 


\subsection{Sequencing}

Sequencing data of the inserts were obtained from Cybergene (Saint-Malo, France). The nucleotide sequences determined for both strands were analysed with PCGene programs.

\section{RESULTS}

First, we checked the reliability of RAPD amplifications with our DNA extracts. Control experiments were carried out on five amounts of Lolium DNA ranging from 10 to $100 \mathrm{ng}$. The results (not shown) confirmed that patterns obtained were identical. Likewise, amplifications, using a given amount of $25 \mathrm{ng}$ DNA per reaction, were performed, each time with new reaction mixes, in order to test the reproducibility of this technique. Patterns obtained after electrophoresis and ethidium bromide staining were roughly identical. Only minor bands showed variable intensities. Though, minor bands were not selected as potential polymorphic markers.

A total of 66 10-mer primers were screened. First, the primers were used for RAPD reactions performed on DNA extracted from genotypes mixes from various species. Out of the primers tested, four gave no amplification products and 17 lead to unclear profiles. This allowed us to identify primers generating profiles containing one or more bright bands present in only one species. Such a profile is shown in figure 1 . Two very bright polymorphic bands are amplified with primer OPH-18. OPH-18 550-bp marker is present in all samples belonging to $L$. perenne $\mathrm{L}$. but absent in all samples belonging to L. multiflorum Lam. On the contrary, OPH-18 512-bp marker is present in all samples belonging to L. multiflorum Lam. but absent in all samples belonging to $L$. perenne $\mathrm{L}$. Seven primers leading to eight polymorphic bands were thus selected (table I).

We further checked the presence of a polymorphic band at the individual level. Amplifications were carried out on DNA from 34 different individuals from one variety of $L$. perenne and from one

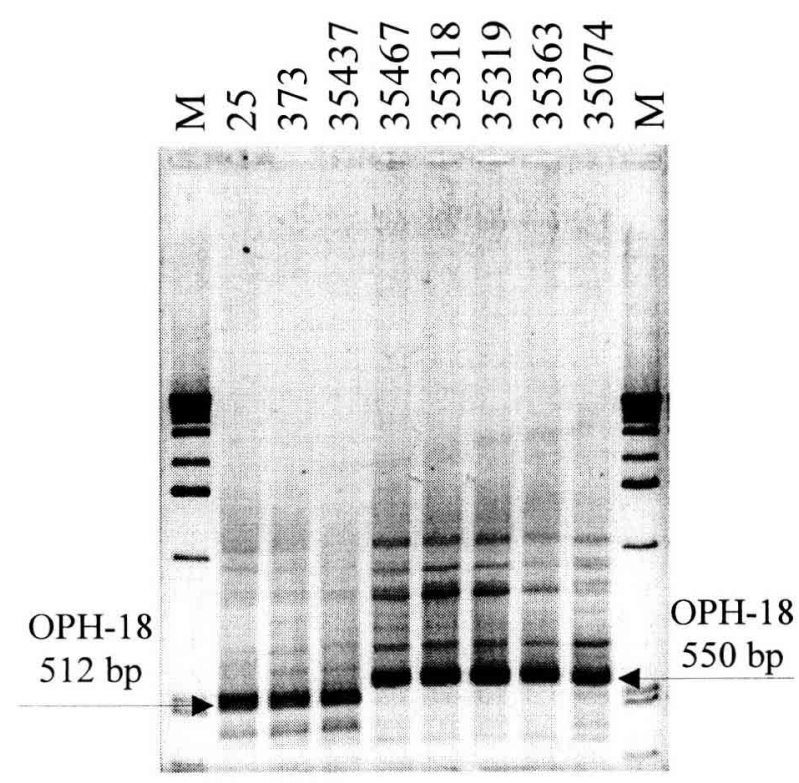

Figure 1: Ethidium bromide-stained (Bet) agarose gel of amplification products obtained with DNA isolated from mixes of plants with oligonucleotide OPH-18. M: molecular weight marker (1-kb ladder from BRL). Lanes 1-3: L. multiflorum Lam. mixes; lanes 4-8: L. perenne L. mixes. Arrows are pointed out on two potential markers. OPH-18 $550 \mathrm{bp}$ is present in all samples belonging to $L$. perenne $\mathrm{L}$. and absent in all samples belonging to L. multiflorum Lam. OPH-18 $512 \mathrm{bp}$ is present in all samples belonging to L. multiflorum Lam. and absent in all samples belonging to L. perenne $\mathrm{L}$.

variety of L. multiflorum. In order to confirm homology between DNA fragments of the same size in different genotypes and to increase detection sensitivity, bands were eluted from gels after electrophoresis of amplification products realized on DNA extractions from mixes of several individuals and they were either directly $\left(\alpha^{32} \mathrm{P}\right)$-dCTP-labelled and used as probes on capillary Southern blotting, or cloned beforehand to be used as probes. In the case of hybridizations realized with fragments eluted from RAPD gels as probes, one major signal is detected at the same size as the probe but many other minor signals are revealed (results not shown), indicating that the gel-isolated fragment was contaminated with other sequences, in sufficient quantity so as to generate a non-specific background in hybridization as demonstrated previously by Lanner et al. [11]. 
Table I. Selected markers generating an interspecific polymorphism between $L$. perenne $\mathrm{L}$. and $L$. multiflorum Lam.

\begin{tabular}{lccc}
\hline Primer & Primer sequence & Marker specificity & $\begin{array}{c}\text { Approximate size of the marker } \\
\text { (in base pairs) }\end{array}$ \\
\hline $70-23$ & 5'-GAGACGTCCC-3' & L. multiflorum Lam. & $500 \mathrm{bp}$ \\
OPH-01 & 5'-GGTCGGAGAA-3' & L. multiflorum Lam. & $400 \mathrm{bp}$ \\
OPH-18 & 5'-GAATCGGCCA -3' & L. multiflorum Lam. & $512 \mathrm{bp}$ \\
OPH-18 & 5'-GAATCGGCCA -3' & L. perenne L. & $550 \mathrm{bp}$ \\
OPG-06 & 5'-GTGCCTAACC-3' & L. perenne L. & $700 \mathrm{bp}$ \\
OPH-04 & 5'-GGAAGTCGCC-3' & L. perenne L. & $700 \mathrm{bp}$ \\
OPH-06 & 5'-ACGCATCGCA-3' & L. perenne L. & $750 \mathrm{bp}$ \\
$70-27$ & 5'-AGCCTGACGC-3' & L. perenne L. & $370 \mathrm{bp}$ \\
\hline
\end{tabular}

In some experiments, the results obtained after ethidium bromide staining were improved by hybridization data. Some bands, at the same size as the marker, that were not detectable after electrophoresis and ethidium bromide staining were revealed, indicating that the sequence was present but faintly amplified with the RAPD technique. Thus, screening for a species-specific sequence is improved by the additional work implied by hybridization. Actually, if a marker, whose presence was only detected in one species after coloration, could be revealed after hybridization in one or more individuals of the other species, it could still not be considered as a species-specific one.

A species-specific marker must possess two properties: presence in all individuals from one species; and absence in all individuals from the other species. Out of eight markers, six were proved to be not species specific. We could distinguish three cases: markers which are present in all individuals of one species but also in some individuals of the other species, such as the 70-23 (500 bp) marker; markers which were present at a high level in one species but not in all individuals and which were also revealed in few individuals of the other species, such as the OPH-01 (400 bp), OPH-04 (700 bp) and OPH-06 (750 bp) markers; markers which were absent in all individuals belonging to one species but not present in all individual of the other species, such as the OPG-06 (700 bp) marker.

In a second step, we studied the distribution of these six markers at the individual level. It means that we determined how many individuals from $L$. perenne possess one, two or more markers first retained as specific to $L$. multiflorum, and vice versa. Seventeen individuals from $L$. perenne and 13 from L. multiflorum exhibit one of these six markers. Likewise, five individuals from $L$. perenne and two from $L$. multiflorum possess two of these six markers. No individual has more than two markers first retained as specific to the other variety.

The other markers retained, OP H-18 550 bp and OPH-18 512 bp, appeared species specific in the studied sample as they were amplified in all genotypes belonging to $L$. perenne $L$. var. 'baltic' and $L$. multiflorum Lam. var. 'wewo westerworld', respectively, and absent in all genotypes belonging to $L$. multiflorum Lam. var. 'wewo westerworld' and $L$. perenne L. var. 'baltic', respectively. Hybridization results showed a strong homology between OPH-18 550 bp and OPH-18 512 bp as these two markers cross-hybridize. Both markers were cloned and the sequences obtained after sequencing are shown in figure 2: OP $\mathrm{H}-18512$ bp shows a $37-b p$ deletion with regards OP H-18 $550 \mathrm{bp}$ and only five mismatches. Computer-based sequence-similarity searches performed with the BLAST network service revealed that the sequence showed strong homology (over $95 \%$ identity) with monocot chloroplastic gene coding for cytochrome b 559 (psbE and psbF genes). Two primers (RG1 and RG2) were derived from the sequences (figure 2) leading to amplification of 488-bp and 451-bp fragments for $L$. perenne L. and $L$. multiflorum Lam., respectively. Their precence were further checked at the individual level (figure 3). In order to confirm the species specificity of both markers, seven other varieties were further studied. The analyses were 


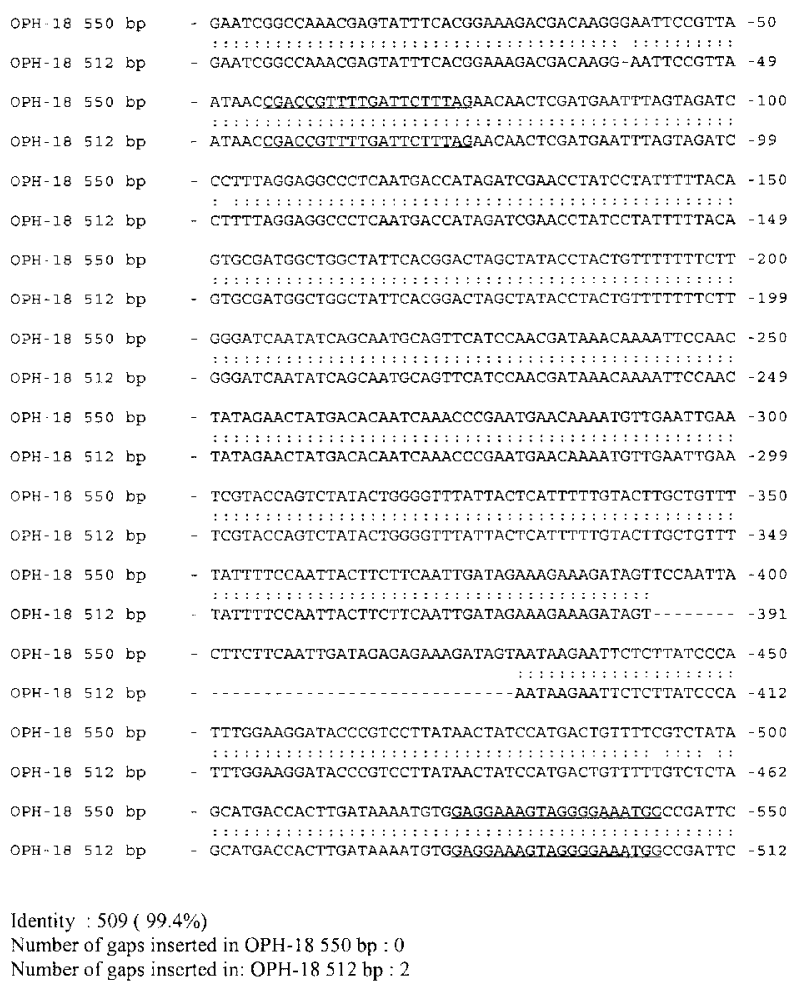

Figure 2. Alignment of the two markers sequences: OPH-18 $550 \mathrm{bp}$ and $\mathrm{OPH}-18512 \mathrm{bp}$. The underlined sequences correspond to the primers synthesised for PCR analysis.

performed on 35 plant (approx.) bulks. After amplification using primers RG1 and RG2, the three $L$. perenne $\mathrm{L}$. varieties exhibit the 488-bp fragment and the four $L$. multiflorum Lam. varieties exhibit the 451-bp fragment (figure 4), although other minor bands were detected.

As the final aim of our work was the detection of contaminant in seed batches, we determined the sensitivity of detection of the species-specific sequence. The PCR detection limit of markers was estimated at $10 \mathrm{pg}$ of template DNA using various amount of Lolium DNA and the PCR parameters described in Material and methods (data not shown).

\section{DISCUSSION}

We have chosen to use RAPD as a tool to screen species-specific sequences, the final aim of this
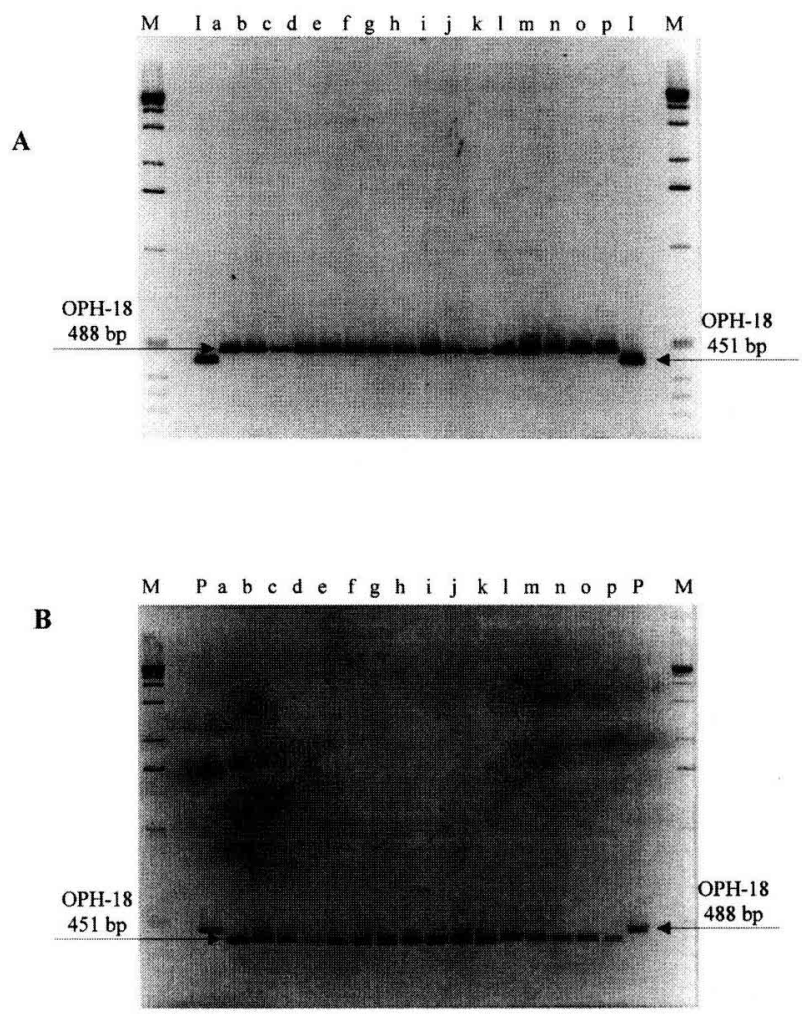

Figure 3. Ethidium bromide-stained agarose gels of PCR amplification products obtained with oligonucleotides RG1 and RG2, synthesized after OPH-18 550-bp sequencing, on DNA isolated from individual plants. $M$ : molecular weight marker. A) Lanes $\mathrm{a}-\mathrm{p}$ : individuals from $L$. perenne $\mathrm{L}$. var 'baltic'; I: Italian ryegrass DNA. B) Lanes a-p: individuals from L. multiflorum Lam. var 'wewo westerworld'; P: perennial ryegrass DNA. Arrows indicate the potential interspecific markers (OPH-18 488 bp and OPH-18 451 bp) obtained after bulk analysis.

work being to develop sequence characterized amplified regions (SCARs) [9]. A good SCAR for detection of specific contamination should be present in all individuals belonging to one of the two species and absent in all individuals belonging to the other species. Although Kesseli et al. [9] reported some trouble concerning reproducibility of the RAPD technique, Penner et al. [21] showed that patterns can be reproducible among laboratories if reaction conditions are strictly followed. Furthermore, Koller et al. [10] showed for apple cultivars that PCR amplifications patterns were robust over a wide range of DNA concentrations. In preliminary analyses, we confirmed that RAPD 


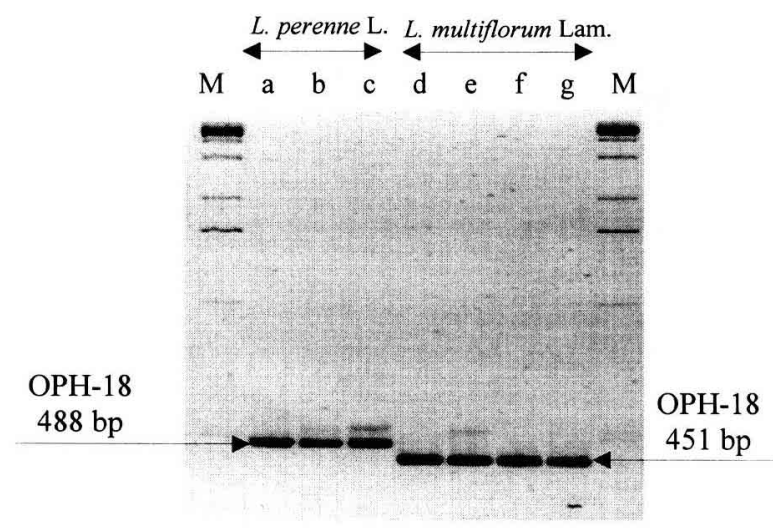

Figure 4. Ethidium bromide-stained agarose gels of PCR amplification products obtained with oligonucleotides RG1 and RG2 (hybridization temperature for amplification: $55^{\circ} \mathrm{C}$ ), on three varieties from $L$. perenne $L$. (lanes a-c) and four from L. multiflorum Lam. (lanes $\mathrm{d}-\mathrm{g}$ ). M: molecular weight marker. $L$. perenne L. varieties: a, Herbie; b, Bastion; c, Barcredo. $L$. multiflorum Lam. varieties: d, Adret; e, Tonyl; f, Vitesse; g, Barspectra. Arrows indicate the species-specific markers, OPH-18 488 bp and OPH-18 451 bp.

technique is reproducible and supports some variations in DNA concentration.

In bulk analysis, the sensitivity of RAPD to detect a poorly represented marker is about six individuals in a 30 -individual bulk [14]. Thus, markers first retained as absent in one species could be present in five out 30 individuals but not detected. Then, we checked 34 individuals, for each variety chosen in each species, in order to refine the previous screening and to eliminate markers which were revealed to be not species specific after plant to plant analysis.

\subsection{RAPD markers and varietal identification}

In bulk studies, we observed RAPD bands characteristic of each species, that is to say, present in one species and absent in the other one. Nevertheless, for six of the eight selected markers, plant to plant analysis revealed the presence of these bands in some individuals from the other species or the absence in some individuals of the species. The proportion of such individuals has been determined for each of these markers. Our results are in agreement with Charmet and Balfourier [1], who distinguished the two species only by the mean allelic frequency of some isoenzyme. One can similarly use the markers revealed in bulk analysis for varietal identification. The estimation of the frequency of each marker in a variety could be performed as follows: moving PCR parameters (hybridization temperature, cycles number, etc.) would allow us to define experimental conditions for the detection of a band, after ethidium bromide staining, only if the level of presence exceeds a definite threshold. Accumulating such data for a sufficient number of markers will then allow varietal identification. This involves cloning and sequencing of the selected markers in order to synthesize the longer primers (20-mers) needed for PCR. Nevertheless, this approach cannot be used to detect $L$. multiflorum Lam. contamination in a batch of $L$. perenne $\mathrm{L}$. seeds and vice versa, as the studied marker is present at a variable level in both populations. Actually, if markers, spread at a low level over population, are detected, we will not be able to determine if the results are due to a contamination or if the population behaves slightly differently from the control.

\subsection{RAPD as a tool to screen species-specific SCARs}

We revealed two species-specific markers in the sample studied as they were present in all tested genotypes belonging to one species and absent in all tested genotypes belonging to the other. Hybridization experiments revealed that both markers showed a very strong homology. Their sequences allowed us to determine that they are chloroplastic ones, OPH-18 512 bp showing a deletion with regards the OPH-18 550 bp marker. The spreading out of both markers was confirmed on seven more varieties of Lolium. Other studies should be performed to analyse the distribution of both types in natural populations. This will demonstrate whether cytotypes are spread in some popula- 
tions of both species, especially in the sympatric zone.

We can wonder if the variations between both markers could be related to an evolution event for both species. The natural dispersion of both species is different, $L$. perenne $\mathrm{L}$. having a preference for wet and cool soils [25], whereas L. multiflorum Lam. is a natural species of irrigated and warmer areas, but all authors admit genetic proximity between both species whatever the evolutionary theory considered. According to Malik and Thomas [12], all allogamous species in the genus Lolium are derived from a common ancestor, from which $L$. rigidum is the closest form. Both chloroplast genomes could have evolved leading to two different chlorotypes. For Essad [6], quoted by Malik and Thomas [12], this ancestor could be L. perenne L. while, for Jenkin [8] quoted by Essad [5], $L$. perenne L. would be the result of South to North evolution of $L$. multiflorum Lam., with successive mutations. Both hypotheses could support an insertion or a deletion in the chloroplast genome during the radiation of the ancestor species.

Although both species studied are genetically very closely related, and genetically heterogeneous, the RAPD technique was shown to be convenient for detecting species-specific sequences. Thus, two homologous chloroplast sequences were revealed. Screening of other markers would improve detection of contaminants. If some individuals from a species did not exhibit one species-specific marker, it seem unlikely that they would lack three or more species-specific markers.

The detection limit was estimated at $10 \mathrm{pg}$ of DNA template for each marker. This means that at least $250 \mathrm{ng}$ of DNA (25000 seeds $\times 10 \mathrm{pg}$ ) would be required to detect one single contaminant in a batch. In order to avoid the use of such a DNA amount for PCR, it would be better to fractionate, prior to DNA extraction, the batch into ten or more sub-samples of seeds. Even in this case, the crucial condition would be the homogeneity of the grinding. Actually, if a single seed contaminates a batch the homogeneity of the powder must be perfect without loss of any material in order to guarantee that each DNA extract is representative of the seed batch composition. Such a precision could only be reached with automated grinders which have to be developed or adapted for seed DNA extraction.

Screening for species-specific sequences for grasses, which are mostly cultivated as synthetic varieties and so highly heterozygous, represents a delicate problem. An appropriate combination of RAPD, bulk analysis and plant to plant analysis, allowed us to isolate two species-specific markers convenient for the detection of contamination.

V. Delozier was supported by a grant from "Région des Pays de la Loire". We are indebted to B. Hamon and C. Ricoult for helpful technical assistance.

\section{REFERENCES}

[1] Charmet G., Balfourier F., Isozyme variation and species relationships in the genus Lolium L. (ryegrasses, Graminaceae), Theor. Appl. Genet. 87 (1994) 641-649.

[2] Charmet G., Ravel C., Balfourier F., Phylogenetic analysis in the Festuca-Lolium complex using molecular markers and ITS rDNA, Theor. Appl. Genet. 94 (1997) 1038-1046.

[3] Crescini F., Plante Erbacee Coltivate, 4th ed., Ramo editoriale degli agricoltori, 1969, pp. 549-555.

[4] Dellaporta S.L., Wood J., Hicks J.B., A plant DNA micropreparation: version II, Plant Mol. Biol. 1 (1983) 19-21.

[5] Essad S., Contribution à la systématique du genre Lolium, Annal. Inra Paris, Série B4 (1954) 325-351.

[6] Essad S., Etude génétique et cytogénétique des espèces de Lolium perenne L., Festuca pratensis Huds. et de leurs hybrides, Inra, série $A, \mathrm{~N}^{\circ}$ Orsay, $\mathrm{N}^{\circ}$ ordre 8 , 1962.

[7] Hill M., Witsenboer H., Zabeau M., Vos P., Kesseli R., Michelmore R., PCR-based fingerprinting using AFLPs as a tool for studying genetic relationships in Lactuca spp., Theor. Appl. Genet. 93 (1996) 1202-1210.

[8] Jenkin T.J., Genetic problems in the breeding of orage grasses, in: Atti del Convegno di Genetica Agraria, 1950, pp. 360-374.

[9] Kesseli R.V., Paran I., Michelmore R.W., Efficient mapping of specifically targeted genomic regions ant the tagging of these regions with reliable 
PCR-based genetic markers, in: Proc. Symp. Applications of RAPD Technology to Plant Breeding, Joint Plant Breeding Sympasia Series, Minneapolis, 1992, pp. 31-36.

[10] Koller B., Lehmann A., McDermott J.M., Gessler C., Identification of apple cultivars using RAPD markers, Theor. Appl. Genet. 85 (1993) 901-904.

[11] Lanner C., Bryngelsson T., Gustafsson M., Genetic validity of RAPD markers at the intra- and interspecific level in wild Brassica species with $n=9$, Theor. Appl. Genet. 93 (1996) 9-14.

[12] Malik C.P., Thomas P.T., Karyotypic studies in some Lolium and Festuca species, Caryologia 19 (1966) 167-196.

[13] Meunier J.R., Grimont P.A.D., Factors affecting reproducibility of random amplified polymorphic DNA fingerprinting, Res. Microbiol. 144 (1993) 373-379.

[14] Michelmore R.W., Paran I., Kesseli R.V., Identification of markers linked to disease-resistance genes by bulked segregant analysis: A rapid method to detect markers in specific genomic regions by using segregating populations, Proc. Natl. Acad. Sci. USA 88 (1991) 9828-9832.

[15] Mita G., Dani M., Casciari P., Pasquali A., Selva E., Minganti C., Piccardi P., Assessment of the degree of genetic variation in beet based on RFLP analysis and the taxonomy of Beta, Euphytica 55 (1991) 1-6.

[16] Moreau E., Berville A., A dot blot assay for the routine determination of maintainer contaminants in cytoplasmic male sterile seed stocks of sunflower (Helianthus annuus L.), Plant Var. Seeds 4 (1991) 31-36.

[17] Naylor B., Species differentiation in the genus Lolium, Heredity 15 (1960) 219-233.

[18] Nei M.: Molecular Evolutionary Genetics, Columbia University Press, New York, 1987.

[19] Paran I., Michelmore R.W., Development of reliable PCR-based markers linked to downy mildew resistance gene in lettuce, Theor. Appl. Genet. 85 (1993) 985-993.
[20] Pecchioni N., Stanca A.M., Terzi V., Cattivelli L., RFLP analysis of higly polymorphic loci in barley, Theor. Appl. Genet. 85 (1993) 926-930.

[21] Penner G.A., Bush A., Wise R., Kim W., Domier L., Kasha K., Laroche A., Scoles G., Molnar S.J., Fedak G., Reproducibility of random amplified polymorphic DNA (RAPD) analysis among laboratories, PCR Methods and Applications (1993) 341-345.

[22] Saiki R.K., Gelfand D.H., Stoffel S., Schart S.J., Higurchi R., Horn G.T., Mullis K.B., Erlich H.A., Primer-directed enzymatic amplification of DNA with a thermostable DNA polymerase, Science 239 (1988) 487-491.

[23] Sambrook J., Fritisch E.F., Maniatis T.: Molecular Cloning: a Laboratory Manual, 2nd ed., 1989.

[24] Santoni S., Faivre-Rampant P., Moreau E., Berville A., Rapid control of purity for the cytoplasm of male-sterile seed stocks by means of a dot hybridization assay, Mol. Cell. Probes 5 (1991) 1-9.

[25] Soltner D., Les grandes productions végétales, Collection: Sciences et Techniques Agricoles, 18th ed., 1995.

[26] Southern E., Detection of specific sequences among DNA fragments separated by gel electrophoresis, J. Mol. Biol. 98 (1975) 503-517.

[27] Stammers M., Harris J., Evans G.M., Hayward M.D., Forster J.W., Use of random PCR (RAPD) technology to analyse phylogenetic relationships in the Lolium/Festuca complex, Heredity 74 (1995) 19-27.

[28] Tautz D., Renz M., An optimized squeeze-freeze method for the recovery of DNA from agarose gels, Anal. Biochem. 132 (1983) 14-19.

[29] Terell E.E., A taxonomic revision of the genus Lolium, Tech. Bull. USDA 1392 (1968) 1-65.

[30] Welsh J., McClelland M., Fingerprinting genomes using PCR with arbitrary primers, Nucleic Acids Res. 18 (1990) 7213-7224.

[31] Williams J.G.K., Kubelik A.R., Livak K.J., Rafalski J.A., Tingey S.V., DNA polymorphisms amplified by arbitrary primers are useful as genetic markers, Nucleic Acids Res. 18 (1990) 6531-6535. 